\title{
Preventive effects of shiitake mushroom extract on candida stomatitis
}

\author{
Hyun-Jun Yoo* \\ Department of Preventive Dentistry, College of Dentistry, Dankook University, Cheonan, Republic of Korea
}

Purpose: The purpose of this study was to investigate antifungal activity of shiitake mushroom yeast and hyphal type of Candida albicans. Materials and Methods: The extract from shiitake mushroom was collected by drying the supernatant after soaking shiitake mushrooms in water or ethanol. The antifungal activity of the extracts against yeast type of $C$. albicans was investigated by the susceptibility assay using microplate. C. albicans biofilm was formed on 12-well plate using Ham's $\mathrm{F}-12$ medium in $\mathrm{CO}_{2}$ incubator and treated with the ethanol extract. Furthermore, $C$. albicans biofilm was formed on denture base resin disk and treated with or without the ethanol extract in the presence of denture cleanser. Live $C$. albicans in biofilm was counted by cultured colony forming unit value after inoculated on agar plate. Results: Ethanol extract from shiitake mushroom showed stronger antifungal activity against yeast type of $C$. albicans compared to its water extract. The ethanol extract significantly reduced count of $C$. albicans in hyphal biofilm $(P<0.05)$. Also, the ethanol extract showed synergistically antifungal effect with denture cleanser on candidal biofilm on denture base resin disk $(P<0.05)$. Conclusion: The ethanol extract of shiitake mushroom may be a candidate for preventing candidal stomatitis as well as denture-related stomatitis. (J Dent Rehabil Appl Sci 2021;37(3):123-9)

Key words: C. albicans; candidal stomatitis; extract of shiitake mushroom

\section{Introduction}

Shiitake mushrooms are one of the most popular mushrooms worldwide. Among shitake mushroom, Lentinula edodes is the most famous and has been most commonly used food and traditional medicine. ${ }^{1}$ Shiitake mushroom has shown to present medicinal compounds such as polysaccharides, sterols, terpenoids, and lipoids, by which has anti-inflammatory, antimicrobial, anti-tumor effects. ${ }^{2,3}$ Also, the extract from this mushroom showed antimicrobial and antibiofilm activity against oral bacteria and biofilm. ${ }^{4,5}$

Candida species are detected up to $90 \%$ in healthy persons and present in the oral cavity of up to $75 \%$ of the population. ${ }^{6,7}$ Furthermore, Candida albicans

${ }^{*}$ Correspondence to: Hyun-Jun Yoo

Assistant Professor, Department of Preventive Dentistry, College of Dentistry,

Dankook University, 119 Dandae-ro, Dongnam-gu, Cheonan, 31116, Republic of Korea

Tel: +82-41-550-1954, Fax: +82-41-550-1859, E-mail: dent.preventive@dankook.ac.kr

Received: June 9, 2021/Last Revision: July 3, 2021/Accepted: July 20, 2021 was identified about $80 \%$ of the isolated Candida species. ${ }^{8}$ The characteristic related to the virulence of C. albicans is the change of morphology which grow either budding yeast and hyphal form by growth condition. 'The morphology of this fungus is changed by environmental $\mathrm{pH}$, physiological temperature, serum and $\mathrm{CO}_{2}{ }^{6}$ The yeast forms are commonly found on the mucosal surface, and the hyphal forms are detected in epithelial layer. ${ }^{10}$ Furthermore, hyphal form but not yeast form are found in epithelial layer at sites of infection. ${ }^{11}$ Therefore, the transition between yeast and hyphal forms is termed dimorphism, that is an important pathogenicity for oral candidiasis. Also, when the virulence of C. albicans is analyzed by global analysis using 177 mutant strains tested,

Copyright $\odot 2021$ The Korean Academy of Stomatognathic Function and Occlusion. (c) It is identical to Creative Commons Non-Commercial License. 
attenuation of the virulence was significantly correlated with reduced hyphal morphogenesis. ${ }^{12}$ Another characteristic of C. albicans is possible to form biofilm of hyphal type on denture. The biofilm formed on denture induces denture related stomatitis.

The elderly population is gradually increasing due to the development of medical technology and equipment. This phenomenon can be expected to increase the use of dentures. Therefore, the aim of this study was to investigated antifungal activity of shiitake mushroom against yeast and hyphal type of C. albicans.

\section{Materials and Methods}

Shiitake mushroom was used Lentinula edodes. Slide shiitake mushroom (300 g) was soaked in 500 $\mathrm{ml}$ of distilled water or ethyl alcohol with magnetic bar. The prepared mushroom was incubated at room temperature for $24 \mathrm{~h}$ on magnetic stirrer. The extract from the mushroom was collected by filtering with Whatman filter paper (GE healthcare, Chicago, USA), and the solvent was evaporated with vacuum evaporator (IKA, Staufen, Germany). The weight of the dried extract was measured and solved at $1 \mathrm{~g} / \mathrm{ml}$ with distilled water and ethyl alcohol. The solution was filtrated with polyvinylidene fluoride (PVDF) filter $(0.25 \mu \mathrm{m}$ of pore size) (Millipore, Billerica, USA).

Candida albicans ATCC 10231 was used in this study. The fungus was cultivated in trypticase soy broth (TSB; BD biosciences, San jose, USA) at $37^{\circ} \mathrm{C}$ in shaking incubator. Furthermore, to form $C$. albicans biofilm with hyphal type, C. albicans was cultivated with Ham's F-12 medium (Hyclone, Logan, USA) at $37^{\circ} \mathrm{C}$ in an incubator under $5 \% \mathrm{CO}_{2}$ condition.

The antifungal activity of shiitake extract was processed by the methods by protocol of Clinical Laboratory Standard. ${ }^{13} 180 \mu \mathrm{l}$ of TSB was dispensed into the well of a 96-well plate (SPL Lifescience, Pocheon, Korea), and the solution of the shiitake extracts were added into the $12^{\text {th }}$ row of well containing TSB. The extract was performed 2-fold serial dilutions from 11 th column to $2^{\text {nd }}$ column with micropipette. The fungus was counted with a hemacytometer (Marienfeld, Lauda-Konigshöfen, Germany) and adjusted the concentration to $1 \times 10^{6}$ cells $/ \mathrm{ml}$ in TSB. $20 \mu$ 1 of the suspension was inoculated into the prepared well. The plate was incubated $37^{\circ} \mathrm{C}$ under aerobic condition for $36 \mathrm{~h}$. The fungal growth was measured with optical density at a $600 \mathrm{~nm}$ wavelength by a microplate reader (Biotek, Winooski, USA). Hyphal C. albicans was formed on 12-well plate using Ham' s F-12. After observe the hyphal type using a phase contrast microscope, the antifungal activity of the shiitake extract was investigated. The ethanol was diluted with phosphate buffered saline (PBS, $\mathrm{pH}$ 7.2) at $12.5,25$, and $50 \mathrm{mg} / \mathrm{ml}$ of concentration. The extract was treated on hyphal C. albicans for $1 \mathrm{~min}$, and hyphal $C$. albicans on the well was disrupted with a scraper (SPL bioscience). The fungal suspension was transferred into $1.5 \mathrm{ml}$ tube and serially diluted from 10 to $10^{5}$ fold. $50 \mu \mathrm{l}$ of the diluted suspension was inoculated on trypticase soy agar (TSA) plate. The plate was incubated $37^{\circ} \mathrm{C}$ for $36 \mathrm{~h}$, and the fungal colonies were counted. To evaluate effect of the extract on denture-related stomatitis, A specimen was fabricated using a 3D printer (Form 2; formlabs Co., Somerville, USA) and acrylic resin (digital Denture resins; formlabs Co.). The specimens were printed with a diameter of $12 \mathrm{~mm}$ with a thickness of 2 $\mathrm{mm}$ parallel to the bottom of the LASER. Next, the surface of the specimens was washed with isopropyl alcohol and cured using ultra violet and heating. Enzyme based denture cleanser (Dongahwa, Seoul, Korea) solved with $100 \mathrm{ml}$ of sterile tap water, and the extract $(25 \mathrm{mg} / \mathrm{ml})$ was solution was added into the solution. Candidal biofilm formed disk were placed into the solution. After incubating for $5 \mathrm{~min}$, the disks were washed with sterile tap water and placed into each well of 12-well polystyrene plate (SPL Lifescience) containing $1 \mathrm{ml}$ of TSB. Candidal biofilm on the disk was physically disrupted with a scraper (SPL bioscience). The fungal suspension was transferred into $1.5 \mathrm{ml}$ tube and serially diluted from 10 to $10^{5}$-fold. $50 \mu \mathrm{l}$ of the diluted suspension was inoculated on trypticase soy agar plate. The plate was incubated $37^{\circ}$ $\mathrm{C}$ for $36 \mathrm{~h}$, and the fungal colonies were counted.

IBM SPSS Statistics Ver. 23 (IBM, Armonk, USA) was used for statistical analysis. In order to analyze the statistical difference in the data, data distribution 
was determined using the Kolmogorov-Smirnov test. The values among groups were analyzed by a nonparametric Kruskal-Wallis test and Mann-Whitney U-test, and statistical significance was defined by a $P$ value of less than 0.05 .

\section{Results}

First, Ethanol and water extract from shiitake mushroom was investigated against yeast type of $C$. albicans. The ethanol extract significantly inhibited the growth of C. albicans above $6.25 \mathrm{mg} / \mathrm{ml}$ of concentration $(P<0.05)$, and the water extract inhibited the candidal growth above $25 \mathrm{mg} / \mathrm{ml}$ of concentration $(P<0.05$, Fig. 1). The ethanol extract showed more antifungal activity compared to the water extract.

As the concentration of the ethanol extract increased, it showed strong fungicidal effect on hyphal biofilm (Fig. 2). However, the water extract did not show antifungal activity against hyphal biofilm (data not shown). The ethanol extract significantly showed antifungal activity against candidal biofilm above 25 $\mathrm{mg} / \mathrm{ml}$ of concentration $(P<0.05)$.
Generally, most elderly people use denture cleansers to remove fungus and debris on denture. Therefore, the antifungal effect of a mixture of denture cleanser and the shiitake extract was investigated. Denture cleanser has strong antifungal activity against candidal biofilm on denture. However, the cleanser did not completely remove C. albicans (Fig. 3). The denture cleanser solution containing the shiitake extract showed more antifungal activity against candidal biofilm on denture compared to single condition of the cleanser.

\section{Discussion}

C. albicans causes oral candidiasis, which is especially common in immune compromised patients or the elderly. ${ }^{1415}$ Also, denture stomatitis occurs in people who wear dentures and is associated with C. albicans. ${ }^{16}$ The elderly population is gradually increasing due to the development of medical technology and equipment. This phenomenon can be expected to increase the use of dentures. Therefore, the importance of denture hygiene is emphasized, and the need for a

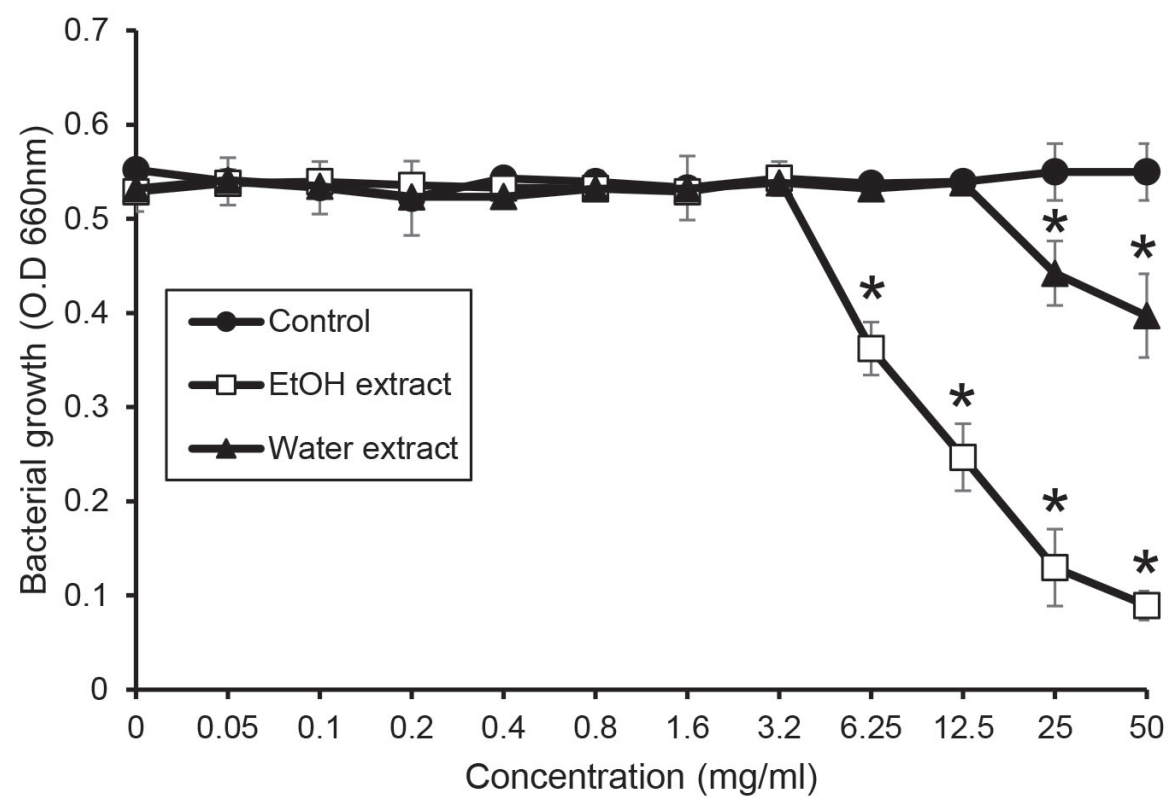

Fig. 1. The antifungal activity of extract from shiitake mushroom on yeast type of C. albicans. C. albicans was cultivated with or without water or ethanol extract from shiitake in the various concentration. The growth of $C$. albicans was measured by a spectrophometer at $660 \mathrm{~nm}$ of wavelength. *symbol indicates significant difference compared to control group $(P<0.05)$. 


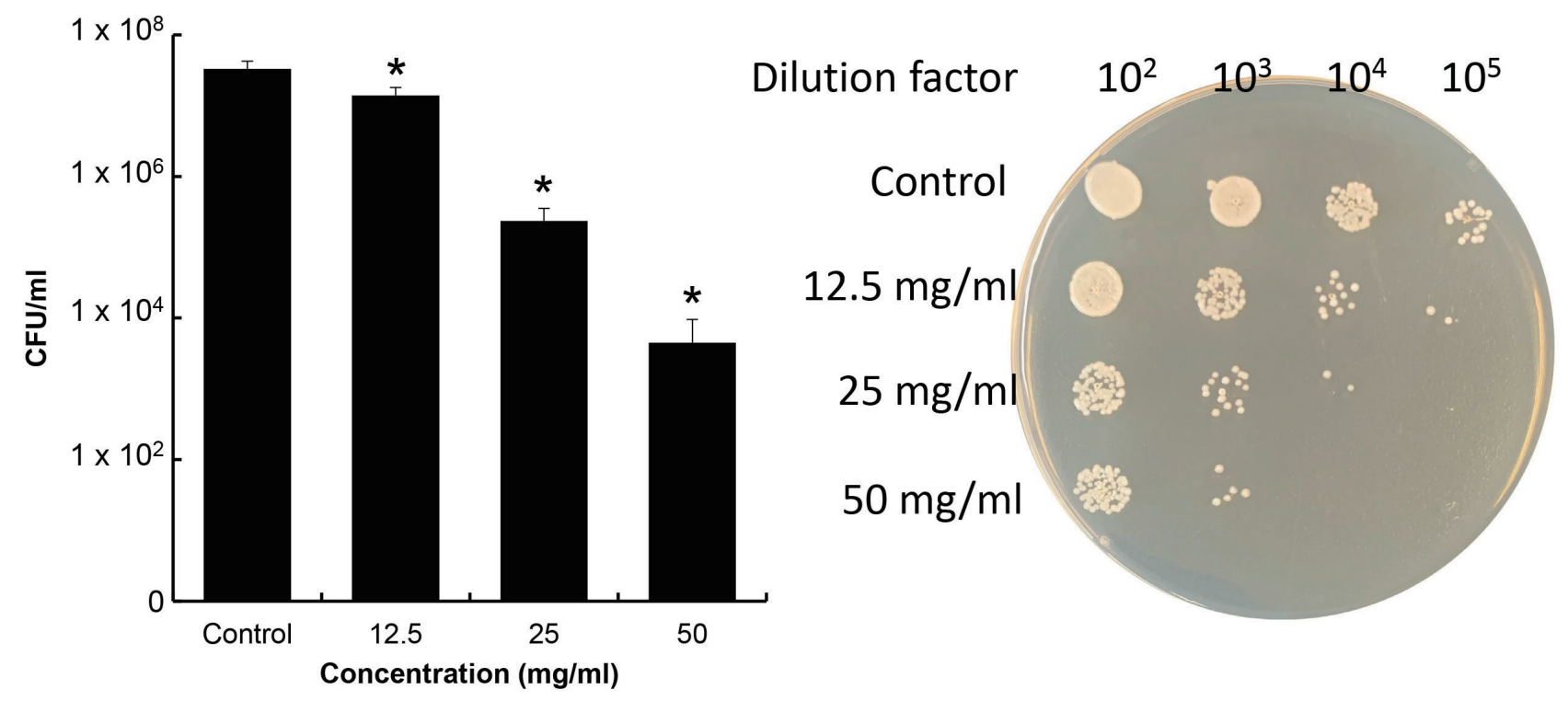

Fig. 2. Effect of the ethanol extract of candidal biofilm. C. albicans was formed biofilm on 12-well plate and treated with the ethanol extract for $1 \mathrm{~min}$. After disrupting biofilm mechanically, C. albicans in the biofilm was resuspended with TSB and inoculated TSA plate. The plate was incubated, and the colonies on the agar plates were counted. *symbol indicates significant difference compared to control group $(P<0.05)$.

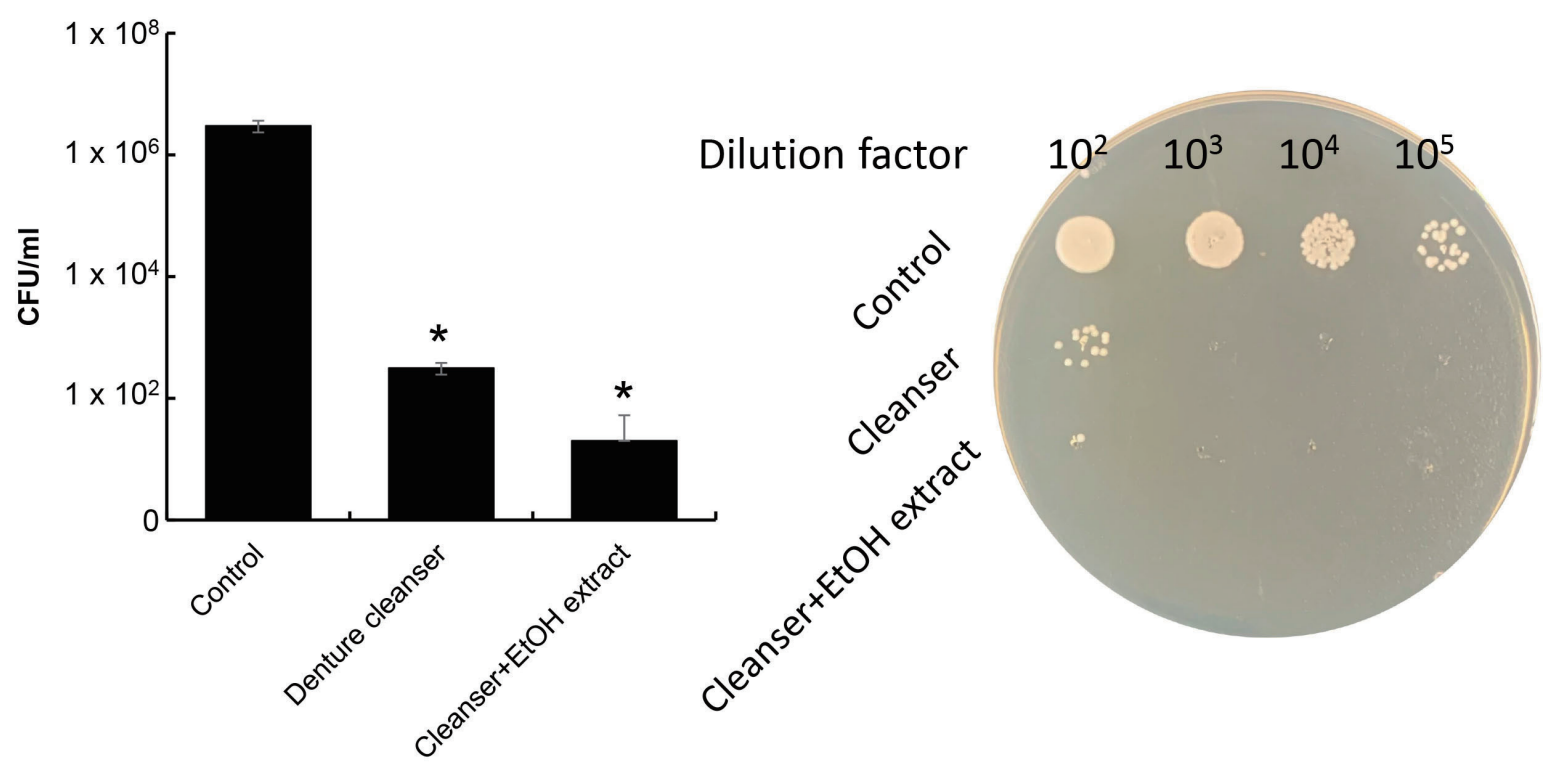

Fig. 3. Synergistic effect of the ethanol extract on reaction of denture cleanser for candidal biofilm on denture base resin. C. albicans was formed biofilm on denture base resin disk. The prepared disk was soaked in denture cleanser solution in the presence or the absence of the ethanol extract. After disrupting biofilm mechanically, $C$. albicans in the biofilm was resuspended with TSB and inoculated TSA plate. The plate was incubated, and the colonies on the agar plates were counted. *symbol indicates significant difference compared to control group $(P<0.05)$. 
more effective denture cleanser is emerging. This study was investigated antifungal activity of extract from shiitake mushroom to prevent oral candidiasis.

Shiitake mushroom is used general food and is recognized medical value due to its nutritional components. This mushroom has bio-active polysaccharide (lentinan, heteroglucan, xylomannan, and $\beta$ -glucan), free sugar (arabinose, arabitol, glycerol, mannitol, mannose, and trehalose), vitamins (B2, B12, C, D and E), organic acid (cinnamic acid, phenolic acid, and benzoic acid), and fiber. ${ }^{17,18}$ These components of shiitake mushroom show antitumor, antiinflammation, antioxidant and antimicrobial activity. ${ }^{1-3,17}$ When extract from shiitake mushroom using water and ethanol was investigated antifungal activity against $C$. albicans, the ethanol extract showed stronger antifungal activity compared to the water extract. These results indicates that hydrophobic components of shiitake mushroom may be suitable to prevent oral candidiasis. Also, comparing other studies. Mushroom extracts with antifungal activity were reported as organic acid such as benzoic acid, cinnamic acid, and phenolic acid, which is consistent with the results of this study. ${ }^{18}$ Basis of these results, the ethanol extract was investigated antifungal activity against hyphal type of $C$. albicans. Since the hyphal type forms biofilm, C. albicans was formed biofilm on 12-well plate to investigated antifungal activity against hyphal type. The ethanol extract showed antifungal activity against hyphal C. albicans. In this study, hyphal C. albicans was evaluated for two reasons. First, the hyphal type forms a biofilm, which forms a protective barrier on the outside of the biofilm with exopolysaccharide. ${ }^{19}$ The protective barrier makes it resistant to antifungal agents, and the resistance to antifungal agents is greater than that of the yeast type. Another reason is that $C$. albicans mainly exists as a hyphal type in oral cavity. Therefore, in order to investigate the antifungal effects in clinical area, it is necessary to use the hyphal type of $C$. albicans. Recently, resistance to antifungal agents of human disease-related fungi is increasing, and thus a treatment is being sought using antifungal agents in crop. ${ }^{20,21}$ Shiitake mushroom is also a crop and may be a candidate to be an agricultural fungicide.
Next, to investigate the effect on denture-related stomatitis, a candidal biofilm was formed on denture resin and its removal ability was tested. Since the antifungal effects of the ethanol extract on candidal biofilm was investigated, the effect when mixed with a denture cleanser was investigated next. The ethanol extract showed a synergistic effect with the denture cleanser on candidal biofilm. This result indicates that the denture cleanser containing enzymes and other constituents had no effect on the ethanol extract. Denture cleanser has been reported to induce oral mucosal injury, chemical burn, and gastric perforation. ${ }^{22-24}$ Therefore, it may be safer denture users by reducing or pulling out the strong toxic substances of denture cleanser and using the extract of shiitake mushroom. In addition, a further study is necessary to investigate antifungal activity against candidal biofilm on denture base resin by using the extract of shiitake mushroom and changing the composition of denture cleanser.

\section{Conclusion}

The present study showed that the ethanol extract from shiitake mushroom has strong antifungal activity against yeast and hyphal type of $C$. albicans. Also, the ethanol extract showed a synergistic effect with the denture cleanser on candidal biofilm on denture. The extract from shiitake mushroom may be a candidate to prevent oral candidiasis.

\section{Acknowledgements}

The present research was supported by a research fund of Dankook University in 2020

\section{ORCID}

Hyun-Jun Yoo https://orcid.org/0000-0002-0100-8309

\section{References}

1. Rao JR, Smyth TJ, Millar BC, Moore JE. Antimicrobial properties of shiitake mushrooms (Lentinula edodes). Int J Antimicrob Agents 2009;33:591-2. 
2. Chien RC, Yen MT, Mau JL. Antimicrobial and antitumor activities of chitosan from shiitake stipes, compared to commercial chitosan from crab shells. Carbohydr Polym 2016;138:259-64.

3. Lull C, Wicher HJ, Savelkoul HF. Antiinflammatory and immunomodulating properties of fungal metabolites. Mediators Inflamm 2005;2005:63-80.

4. Shouji N, Takada K, Fukushima K, Hirasawa M. Anticaries effect of a component from shiitake (an edible mushroom). Caries Res 2000;34:94-8.

5. Ciric L, Tymon A, Zaura E, Lingström P, Stauder M, Papetti A, Signoretto C, Pratten J, Wilson M, Spratt D. In vitro assessment of shiitake mushroom (Lentinula edodes) extract for its antigingivitis activity. J Biomed Biotechnol 2011;2011:507908.

6. Mayer FL, Wilson D, Hube B. Candida albicans pathogenicity mechanisms. Virulence 2013;4:11928.

7. Gornitsky M, Paradisi I, Landaverde G, Malo AM, Velly AM. A clinical and microbiological evaluation of denture cleansers for geriatric patients in long-term care institutions. J Can Dent Assoc 2002;68:39-45.

8. Coronado-Castellote L, Jiménez-Soriano Y. Clinical and microbiological diagnosis of oral candidiasis. J Clin Exp Dent 2013;5:279-86.

9. Gow NA, van de Veerdonk FL, Brown AJ, Netea MG. Candida albicans morphogenesis and host defence: discriminating invasion from colonization. Nat Rev Microbiol 2011;10:112-22.

10. Zhu W, Filler SG. Interactions of Candida albicans with epithelial cells. Cell Microbiol 2010;12:273-82.

11. Scherwitz C. Ultrastructure of human cutaneous candidosis. J Invest Dermatol 1982;78:200-5.

12. O'Meara TR, Veri AO, Ketela T, Jiang B, Roemer T, Cowen LE. Global analysis of fungal morphology exposes mechanisms of host cell escape. Nat Commun 2015;6:6741.

13. Ghannoum MA, Jurevic RJ, Mukherjee PK, Cui F, Sikaroodi M, Naqvi A, Gillevet PM. Characterization of the oral fungal microbiome (mycobiome) in healthy individuals. PLoS Pathog 2010;6:e1000713.

14. Saral R. Candida and Aspergillus infections in immunocompromised patients: an overview. Rev Infect Dis 1991;13:487-92.
15. Flevari A, Theodorakopoulou M, Velegraki A, Armaganidis A, Dimopoulos G. Treatment of invasive candidiasis in the elderly: a review. Clin Interv Aging 2013;8:1199-208.

16. Pereira-Cenci T, Del Bel Cury AA, Crielaard W, Ten Cate JM. Development of Candida-associated denture stomatitis: new insights. J Appl Oral Sci 2008;16:86-94.

17. Heleno SA, Barros L, Martins A, Queiroz MJ, Santos-Buelga C, Ferreira IC. Phenolic, Polysaccharidic, and Lipidic Fractions of Mushrooms from Northeastern Portugal: Chemical Compounds with Antioxidant Properties. J Agric Food Chem 2012;60:4634-40.

18. Alves MJ, Ferreira IC, Dias J, Teixeira V, Martins A, Pintado M. A review on antifungal activity of mushroom (basidiomycetes) extracts and isolated compounds. Curr Top Med Chem 2013;13:264859.

19. Lal P, Sharma D, Pruthi P, Pruthi V. Exopolysaccharide analysis of biofilm-forming Candida albicans. J Appl Microbiol 2010;109:128-36.

20. Brauer VS, Rezende CP, Pessoni AM, De Paula RG, Rangappa KS, Nayaka SC, Gupta VK, Almeida F. Antifungal Agents in Agriculture: Friends and Foes of Public Health. Biomolecules 2019;9:521.

21. Neji S, Hadrich I, Trabelsi H, Abbes S, Cheikhroubou F, Sellami H, Makni F, Ayadi A. Virulence factors, antifungal susceptibility and molecular mechanisms of azole resistance among Candida parapsilosis complex isolates recovered from clinical specimens. J Biomed Sci 2017;24:67.

22. Murdoch-Kinch CA, Mallatt ME, Miles DA. Oral mucosal injury caused by denture cleanser tablets: a case report. Oral Surg Oral Med Oral Pathol Oral Radiol Endod 1995;80:756-8.

23. Stone C, Sabes WR. Denture cleaner chemical burn. Gen Dent 1995;43:554-5.

24. Ingram DM, Bosse GM, Baldwin R. Ingestion of a denture cleanser: did it cause gastric perforation? J Med Toxicol 2008;4:21-4. 


\section{칸디다성 구내염에 대한 표고버섯 추출물의 예방효과}

\section{유현준* 조교수}

단국대학교 치과대학 예방치과학교실

목적: 본 연구의 목적은 효모형 또는 균사형 Candida albicans에 대한 표고버섯 추출물의항진균효과를 살펴보기 위함이다. 연구 재료 및 방법: 표고버섯 추출물은 표고버섯을 물 또는 에탄올에 닮근 후, 상층액을 건조시켜서 얻었다. 효모형 $C$. albicans에 대한 추출물의 항진균활성은 마이크로플레이트를 이용한 감수성 시험을 이용하여 조사되었다. C. albicans 생물 막을 $\mathrm{CO}_{2}$ 배양기에서 Ham's F-12 배지를 이용하여 12-well 플레이트에 형성시키고 에탄올 추출물로 처리하였다. 또한 C. albicans 생물막을 의치상용 레진 디스크에 형성시키고 의치세정제를 에탄올 추출물이 포함 또는 포함되지 않은 조건 에서 처리하였다. 두 조건의 항바이오필름 효과 시험에서의 바이오필름내 살아있는 C. albicans를 조사하기 위해서 한천고 체배지에 접종한 후 집락 형성 단위(CFU) 값을 측정하였다.

결과: 효모형 C. albicans에 대해서 표고버섯으로부터 물 추출물보다 에탄올 추출물이 강한 항진균력을 보였다. 에탄올 추 출물은 균사형 C. albicans 바이오필름에 대해서도 유의적인 항진균력을 보였다 $(P<0.05)$. 또한 에탄올 추출물은 의치세 정제와 의치에 형성된 C. albicans 바이오필름에 대한 항진균력에 대해서 동반상승효과를 보였다 $(P<0.05)$.

결론: 표고버섯 에탄올 추출물은 구강 칸디다증 예방뿐만 아니라 의치관련 구내염에 대해서 예방할 수 있는 후보물질로 사료된다.

(구강회복응용과학지 2021;37(3):123-9)

주요어: C. albicans; 구강 칸디다증; 표고버섯 추추물

*교신저자: 유현준

(31116) 충청남도 천안시 동남구 단대로 119 , 단국대학교 치과대학 예방치과학교실

Tel: 041-550-1954 | Fax: 041-550-1859 | E-mail: dent. preventive@dankook. ac. kr

접수일: 2021년 6월 9일 | 수정일: 2021년 7월 3일 | 채택일: 2021년 7월 20일 